Journal of Public Sector Innovations, Vol. 4, No. 1, November Tahun 2019, ( 20-29)

\title{
IMPLEMENTASI KEBIJAKAN MANFAAT JAMINAN HARI TUA DI INDONESIA
}

\author{
Putri Wijayanti \\ Fakultas Ilmu Administrasi, Universitas Indonesia, Putri.wijayanti301@gmail.com
}

Lina Miftahul Jannah

Fakultas Ilmu Administrasi, Universitas Indonesia, miftahul@ui.ac.id

\begin{abstract}
Abstrak
Penelitian ini membahas mengenai implementasi kebijakan manfaat Jaminan Hari Tua (JHT) di Indonesia. JHT merupakan salah satu program jaminan sosial ketenagakerjaan dengan manfaat berupa uang tunai yang dapat diberikan kepada peserta ketika memasuki usia pensiun, cacat tetap atau meninggal dunia di Indonesia. Penelitian ini menggunakan metode kualitatif deskriptif dengan teknik pengumpulan data melalui wawancara mendalam dan studi literatur. Hasil dari penelitian ini yakni keberhasilan implementasi kebijakan manfaat JHT di Indonesia sangat dipengaruhi oleh berbagai faktor diantaranya meliputi konten dan konteks dari kebijakan itu sendiri serta kepatuhan dan kondisi sosiologis masyarakat. Keberhasilan Implementasi kebijakan manfaat JHT di Indonesia dalam mencapai tujuannya memerlukan adanya sinkrosisasi pada aspek filosofis, sosiologi dan yuridis dari kebijakan tersebut.
\end{abstract}

Kata kunci : Jaminan Hari Tua, Jaminan Sosial.

\begin{abstract}
This study discusses the implementation of policies on benefits of Old Age Insurance (JHT) in Indonesia. JHT is one of the employment social security programs with benefits in the form of cash that can be given to participants when entering retirement age, permanent disability or death in Indonesia. This study uses descriptive qualitative methods with data collection techniques through in-depth interviews and literature studies. The results of this study, namely the successful implementation of the JHT benefit policy in Indonesia, is strongly influenced by various factors including the content and context of the policy itself as well as the sociological compliance and conditions of the community. The success of implementing the JHT benefit policy in Indonesia in achieving its objectives requires the existence of syncrosization on the philosophical, sociological and juridical aspects of the policy.
\end{abstract}

Keywords : Old Age Insurance, Social Security

\section{PENDAHULUAN}

Ketenagakerjaan merupakan salah satu isu penting di Indonesia karena $68,5 \%$ penduduk berada pada kelompok usia produktif (Bappenas, 2018). Pertumbuhan usia produktif ini diharapkan tumbuh menjadi tenaga kerja yang handal dan kompeten agar mampu menjadi penggerak pembangunan. Pekerja Indonesiaterdiri dari pekerja sektor formal dan sektor informal. Data Sakernas pada bulan Februari 2018 menunjukan bahwa jumlah total tenaga kerja secara menyeluruh sebanyak 127.067.835 juta jiwa yang terdiri atas53.094.391 juta jiwa bekerja pada sektor formal dan 73.973.444 juta jiwa pada sektor informal (Sakernas, 2018).Pertumbuhan tenaga kerja baik sektor formal maupun sektor informal merupakan modal bagi pergerakan pembangunan Indonesia.
Pekerja berhak atas pengupahan yang adil, pemenuhan jaminan sosial dan waktu istirahat.Pemerintahmemberikan perhatian pada kesejahteraan pekerja dengan melakukan telaah atas pengupahan setiap tahunnya melalui penetapan Upah Minimun Regional/Provinsi (UMR/UMP). Peran penting pekerja dalam pergerakan ekonomi negara menekan pemerintah untuk terus memperhatikan kesejahteraannya termasuk kebutuhan hidup layak bagi pekerja.

Pada saat bekerja, seorang pekerja tidak hanya berhak mendapatkan penghasilan yang layak namun juga tunjangan dan jaminan sosial sebagai perlindungan sosial. Perlindungan sosial akan memperhatikan intervensi sosial yang dibentuk untuk membantu individu, rumah tangga, dan masyarakat untuk mengelola risiko dengan lebih 
baik dan memberikan dukungan kepada orangorang yang hampir miskin (Devereaux dan Wheeler,2004). Perlindungan sosial untuk pekerja di Indonesia sudah ada sejak tahun 1992 ditandai dengan terbitnya Undang-Undang Nomor 3 Tahun 1992 Tentang Jaminan Sosial Tenaga Kerja. Pada Tahun 1992, Undang-Undang Jaminan Sosial Tenaga Kerja memiliki 5 program untuk pekerja yaitu Program Jaminan Pemeliharaan Kesehatan, Program Jaminan Kecelakaan Kerja, Program JaminanKematian, Program Jaminan Hari Tua dan Program Jaminan Pensiun. Perlindungan sosial bagi pekerja ini dikelola oleh PT. Jamsostek yang merupakan perusahaan dengan profit oriented.

Undang-Undang Nomor 13 Tahun 2003 TentangKetenagakerjaan menjelaskan pekerja memiliki hak untuk mendapatkan perlindungan atas keselamatan dan kesehatan kerja, moral dan kesusilaan dan perlakuan yang sesuai dengan harkat dan martabat manusia serta nilai-nilai agama. Pada Pasal 99 ayat (1) Undang-Undang Ketenagakerjaan lebih lanjut menegaskan bahwa pekerja dan keluarganya berhak untuk mendapatkan jaminan sosial tenaga kerja. Hal ini menekankan bahwa jaminan sosial bagi tenaga kerja merupakan hal yang penting untuk melindungi pekerja dari kemungkinan yang tidak diinginkan/risiko kerja.

Pada Tahun 2004 terjadi reformasi pada peraturan jaminan sosial. Hal ini ditandai dengan terbitnya Undang-Undang Nomor 40 Tahun 2004 tentang Sistem Jaminan Sosial Nasional (UndangUndang SJSN). Perubahan mendasar bagi jaminan sosial tenaga kerja mencakup kepesertaan untuk mendapatkan manfaat jaminan sosial tidak hanya bagi pekerja formal namun juga pekerja informal. Pemerintah menetapkan bahwa seluruh pekerja harus mengikuti jaminan sosial bagi tenaga kerja dengan kepesertaan bertahap (DJSN, 2014). Peraturan ini menegaskan bahwa Jaminan sosial tenaga kerja di Indonesia saat ini diselenggarakan oleh Badan Penyelenggaran Jaminan Sosial Ketengakaerjaan (BPJS Ketenagakerjaan) yang merupakan badan hukum publik dan menyelenggarakan 4 program yakni (i) Program Jaminan Kecelakaan Kerja (JKK), (ii) Program Jaminan Kematian (JKM), (iii)Program Jaminan Hari Tua (JHT) dan (iv) Program Jaminan Pensiun (JP). Jaminan sosial ini memberikan perlindungan bagi pekerja saat bekerja maupun memasuki masa pensiun (pasca bekerja) dengan peruntukan perlindungan dan kesejahteraan. Jaminan Sosial menjadi hak pekerja untuk menghindari pekerja dari kemiskinan ketika terjadi hal yang tidak diinginkan/risiko.

Sejak terbitnya Undang-Undang SJSN, perumus kebijakan mencoba meluruskan tujuan dari program JHT yang dapat memberikan manfaat besar saat pekerja memasuki usia tua atau pensiun. Peraturan pelaksana dari Undang-Undang SJSN yakni Peraturan Pemerintah Nomor 46 Tahun 2015 Tentang Penyelenggaraan Program Jaminan Hari Tua menjelaskan manfaat Program JHT berupa uang tunai yang dapat dibayarkan sekaligussaat peserta memasuki usia pensiun, meninggal dunia, atau mengalami cacat total tetap. Berdasarkan hal ini, pembayaran manfaat JHT sesuai dengan amanat UU SJSN. Peraturan Pemerintah Nomor 46 Tahun 2015 menjelaskan lebih lanjut adanya manfaat tambahan lain dari dana JHT yakni $10 \%$ untuk kebutuhan persiapan pensiun dan $30 \%$ untuk perumahan dengan kepesertaan 10 tahun.

Undang-Undang SJSN dan Peraturan Pemerintah Nomor 46 Tahun 2015 mendapatkan protes keras dari masyarakat karena kebijakan yang dianggap memberatkan masyarakat. Peran dari Gabungan Serikat Buruh sangat besar dengan memberikan ancaman akan melakukan demonstrasi besar apabila Pemerintah tidak segera merevisi Peraturan Pemerintah Tentang JHT tersebut (https//www.kompas.com, 2015). Tuntuan masyarakat didengar oleh pemerintah sehingga mengeluarkan kebijakan yang memperbarui kebijakan sebelumnya tetapi pada akhirnya kebijakan yang terbit tidak sesuai dengan peraturan perundang-undangan di atasnya yakni UndangUndang SJSN.

Dalam penjelasan Peraturan Pemerintah Nomor 60 Tahun 2015 tersebut tertulis bahwa pensiun termasuk pada berhenti bekerja. Hal ini menekankan bahwa manfaat program JHT dapat dicairkan ketika pekerja berhenti pekerja meskipun belum memasuki usia pensiun. Peraturan Menteri Tenaga Kerja Nomor 19 Tahun 2015 tentang Tata Cara dan Persyaratan Pembayaran Manfaat Jaminan Hari Tua yang merupakan peraturan pelaksana dari Peraturan Pemerintah Nomor 60 Tahun 2015 menjelaskan lebih jauh tentang berhenti bekerja meliputi peserta mengundurkan diri, PHK dan meninggalkan Indonesia untuk selama-lamanya. Peraturan ini bertentangan dengan Undang-Undang SJSN dan telah dibahas dalam penelitian terdahulu (Acie, 2016). Peraturan Menteri Ketenagakerjaan Nomor 19 Tahun 2015 memberikan syarat yang mudah bagi mereka yang terPHK dan 
mengundurkan diri untuk mengambil manfaat JHT walaupun masih dalam usia produktif. Pembayaran manfaat yang dijelaskan tersebut sesuai dengan data berikut :

Tabel 1.2. Pembayaran Manfaat JHT Berdasarkan Jenis Klaim Semester II Tahun 2018

\begin{tabular}{|c|c|c|c|c|c|c|c|}
\hline \multirow{2}{*}{ No. } & \multirow{2}{*}{$\begin{array}{l}\text { Jenis } \\
\text { Klaim }\end{array}$} & \multicolumn{6}{|c|}{ Jumlah Kasus } \\
\hline & & Juli & Agust & Sept & Okt & Nov & Des \\
\hline 1 & $\begin{array}{c}\text { Meng } \\
\text { undurkan } \\
\text { Diri } \\
\end{array}$ & $\begin{array}{l}846 . \\
795\end{array}$ & $\begin{array}{l}971 . \\
046\end{array}$ & $\begin{array}{c}1.096 . \\
550\end{array}$ & $\begin{array}{c}1.239 . \\
640\end{array}$ & $\begin{array}{c}1.372 . \\
042\end{array}$ & $\begin{array}{c}1.487 . \\
572\end{array}$ \\
\hline 2 & PHK & $\begin{array}{l}176 . \\
132\end{array}$ & $\begin{array}{l}202 . \\
704\end{array}$ & $\begin{array}{l}227 . \\
998\end{array}$ & $\begin{array}{l}255 . \\
967\end{array}$ & $\begin{array}{l}281 . \\
681\end{array}$ & $\begin{array}{l}303 . \\
825\end{array}$ \\
\hline 3 & $\begin{array}{l}\text { Mening } \\
\text { galkan } \\
\text { NKRI } \\
\end{array}$ & 2.697 & 3.123 & 3.559 & 3.986 & 4.382 & 4.783 \\
\hline 4 & $\begin{array}{c}5 \text { tahun } 1 \\
\text { bulan }\end{array}$ & 89 & 103 & 107 & 110 & 120 & 123 \\
\hline 5 & $\begin{array}{c}\text { Kepe } \\
\text { sertaan } \\
10 \mathrm{Th}\end{array}$ & $\begin{array}{l}17 . \\
430\end{array}$ & $\begin{array}{l}19 . \\
865\end{array}$ & $\begin{array}{l}22 . \\
416\end{array}$ & $\begin{array}{l}25 . \\
437\end{array}$ & $\begin{array}{l}28 . \\
391\end{array}$ & $\begin{array}{l}30 . \\
702\end{array}$ \\
\hline 6 & $\begin{array}{c}\text { Usia } \\
\text { Pensiun }\end{array}$ & $\begin{array}{l}31 . \\
225\end{array}$ & $\begin{array}{l}36 . \\
057\end{array}$ & $\begin{array}{l}40 . \\
738\end{array}$ & $\begin{array}{l}45 . \\
928\end{array}$ & $\begin{array}{c}50 . \\
398\end{array}$ & $\begin{array}{l}54 . \\
136\end{array}$ \\
\hline 7 & $\begin{array}{l}\text { Cacat } \\
\text { Total } \\
\text { Tetap }\end{array}$ & 21 & 25 & 28 & 30 & 37 & 41 \\
\hline 8 & $\begin{array}{c}\text { Mening } \\
\text { gal dunia }\end{array}$ & $\begin{array}{l}16 . \\
064\end{array}$ & $\begin{array}{l}18 . \\
672 \\
\end{array}$ & $\begin{array}{l}21 . \\
148\end{array}$ & $\begin{array}{l}24 . \\
056\end{array}$ & $\begin{array}{l}26 . \\
767 \\
\end{array}$ & $\begin{array}{l}29 . \\
064\end{array}$ \\
\hline 9 & $\begin{array}{c}\text { Peruba } \\
\text { han status }\end{array}$ & 2 & 2 & 2 & 2 & 2 & 2 \\
\hline & & $\begin{array}{l}1.090 \\
.435\end{array}$ & $\begin{array}{c}1.251 . \\
597\end{array}$ & $\begin{array}{c}1.412 . \\
546\end{array}$ & $\begin{array}{c}1.595 \\
156\end{array}$ & $\begin{array}{c}1.763 \\
820\end{array}$ & $\begin{array}{c}1.910 . \\
248\end{array}$ \\
\hline
\end{tabular}

Sumber : Data olahan peneliti dari laporan BPJS Ketenagakerjaan Semester II Tahun 2018

Klaim dana JHT dengan alasan Peserta berhenti bekerja sebagaimana dimaksud dalam Permenaker Nomor 19 Tahun 2015yaitu karena mengundurkan diri, PHK dan meninggalkan NKRI menjadi angka teratas dalam pembayaran manfaat pada program JHT.Ini menjadi permasalahan karena mengakibatkan berkurang atau bahkan hilangnya manfaat uang tunai yang seharusnya diterima oleh Peserta ketika memasuki usia pensiun, meninggal atau cacat total (Situmorang, 2016). Pada kenyataannya 3 hal tersebut berada pada posisi terbawah dalam pembayaran manfaat JHT. Kondisi ini membuat optimalisasi pembayaraan JHT menurun, hal ini disebabkan penarikan dana yang terus menerus bertambah menyebabkan turunnya presentase dana pengembangan yang dikembalikan kepada peserta. Pergeseran filosofi JHT akibat pelaksanaan Peraturan Pemerintah Nomor 46 Tahun 2015 junto
Peraturan Pemerintah Nomor 60 Tahun 2015 melalui Permenaker Nomor 19 Tahun 2015 menjadikan Jaminan Hari Tua menjadi jaminan hari tertentu ketika peserta PHK atau mengundurkan diri dan tentunya mempengaruhi penerimaan uang JHT di waktu tua.

Kajian ini menarik karena membahas mengenai implementasi kebijakan manfaat jaminan hari tua di Indonesia. Manfaat JHT memiliki permasalahan yang cukup signifikan baik segi regulasi, tata kelola, dan kepatuhan para pelaksana sehingga menyebabkan manfaat JHT belum dapat optimal diterima oleh peserta. Disharmoni regulasi dari Permenaker 19 tahun 2015 membuat peserta kehilangan jaminan di hari tuanya. Tata kelola dari kebijakan manfaat JHT juga memiliki permasalahannya sendiri. Berdasarkan hal tersebut, maka penelitian ini akan menjawab pertanyaan :

1. Bagaimana implementasi kebijakan manfaat jaminan hari tua di Indonesia ?

2. Faktor-faktor yang mempengaruhi implementasi kebijakan manfaat jaminan hari tua di Indonesia?

\section{METODE PENELITIAN}

Penelitian ini menggunakan metode kualitatif untuk mengeksplorasi dan memahami makna yang oleh sejumlah individu atau sekelompok orang dianggap berasal dari masalah sosial atau kemanusiaan. Hal ini senada dengan yang diutarakan oleh Cresswell bahwa penelitian kualitatif ialah suatu upaya penggalian dan pemahaman atas makna dari yang terjadi pada indinvidu dan kelompok atas permasalahan sosial dan kemanusiaan (Cresswell 2009).

Penelitian ini merupakan jenis penelitian deskriptif karena memiliki tujuan untuk memberikan gambaran mendetail suatu keadaan yang terjadi baik baik dengan melihat situasi, latar sosial dan hubungan antara aktor sekaligus implementator yang terkait dengan implementasi kebijakan tata cara dan syarat pembayaran manfaat program JHT. Pengumpulan data yang dilakukan melalui wawancara mendalam dan studi literatur.

\section{HASIL DAN PEMBAHASAN}

1. Implementasi kebijakan manfaat JHT

Kebijakan publik merupakan semua yang pemerintah lakukan atau tidak dilakukan (Anderson, 2003). Hal ini senada dengan yang disampaiakn oleh Thomas Dye yang menjelaskan 
bahwa kebijakan publik mengenais keputusan pemerintah atas apapun untuk memilih untuk melakukan atau tidak melakukan (Dye, 2013). Dalam penelitian ini, kebijakan publik mengenai manfaat JHT merupakan tindakan yang dilakukan pemerintah untuk menyelenggarakan prinsip tabungan wajib yang ditujukan bagi pekerja yang akan memasuki usia pensiun. Penyelenggaraan JHT telah ada sejak tahun 1992 dengan terbitnya Undang-Undangan Nomor 3 tahun 1992 mengenai jaminan sosial tenaga kerja sehingga seluruh pekerja wajib memiliki Jamsostek. Pada era SJSN yang ditandai terbitnya Undang-Undang Nomor 40 Tahun 2004 tentang Undang-Undangan Jaminan Sosial maka jaminan sosial ketenagakerjaan menjadi wajib bagi pekerja baik sektor formal maupun informal. Kebijakan pemberian manfaat jaminan sosial ini merupakan tindakan pemerintah untuk melindungi pekerja di Indonesia.

Kebijakan yang telah ditetapkan tidak ada bermanfaat bila tidak diimplementasikan. Ini seperti yang diutarakan oleh William Dunn bahwa Kebijakan tidak akan berdampak dan tidak dapat mencapai tujuan dari kebijakan itu sendiri apabila kebijakan tersebut tidak diimplementasikan. Proses penting dalam sebuah kebijakan ialah implementasi kebijakan itu sendiri Pentingnya sebuah implementasi kebijakan diperkuat lagi oleh Pressman dan Wildavsky menjelaskan "policy implementation may be viewed as process of interaction between the setting of goals and actions geared to achieved them" bahwa implementasi kebijakan adalah proses interaksi antara tujuan dan tindakan yang dilakukan untuk mencapai tujuan tersebut. Tujuan yang telah disusun akan direalisasikan melalui berbagai kegiatan, bisa dalam program-program untuk mendukung tercapainya tujuan sehingga implemnetasi sebagai sebuah proses menjadi penting untuk capaian tujuan sebuah kebijakan. Dalam kebijakan manfaat JHT maka kebijakan manfaat ini diatur dalam UU SJSN yang menegaskan bahwa manfaat JHT dapat diberikan kepada peserta yang memasuki usia pensiun, cacat tetap dan meninggal dunia. UU SJSN ini dilaksanakan melalui PP 46/2015 yang menegaskan bahwa manfaat JHT dapat diberikan kepada peserta yang memasuki usia pensiun, cacat tetap dan meninggal dunia serta diberikan kelonggaran untuk mengambil setelah kepesertaan 10 tahun dengan besaran $10 \%$ untuk persiapan pensiun dan $30 \%$ untuk kepemilikan perumahan. Kebijakan ini direspon oleh Serikat Pekerja yang keberatan dengan pengambilan manfaat JHT dengan syarat 10 tahun kepesertaan dengan anggapan waktu yang terlalu lama. Hasil wawancara dengan Timboel Siregar selaku Koordinator BPJS Watch menyatakan bahwa pada saat ini tuntutan serikat Pekerja ialah mengembalikan kepada syarat JHT yang sebelumnya yakni merujuk pada Undang-Undang Jaminan Sosial Tenaga Kerja tahun 1992 yang menekankan pengambilan manfaat JHT pada kepesertaan 5 tahun 1 bulan. Timboel menambahkan terdapat kekurangan dalam UU SJSN karena tidak mengatur adanya kondisi tertentu dalam pengambilan manfaat JHT. Dalam UU Jamsostek 1992 maka kondisi tertentu ini yang didefinisikan pengambilan manfaat JHT dengan syarat kepesertaan 5 tahun 1 bulan. Peran dari Gabungan Serikat Buruh sangat besar dengan memberikan ancaman akan melakukan demonstrasi besar apabila Pemerintah tidak segera merevisi Peraturan Pemerintah Tentang JHT tersebut (https//www.kompas.com, 2015).

Dalam wawancara yang dilakukan terhadap Plt. Sekretaris Dewan Jaminan Sosial Nasional (DJSN), Linda Darnel menjelaskan klaim yang terjadi secara besar-besar di bulan Juli 2015 dikarenakan tidak adanya masa transisi dari kebijakan manfaat itu sendiri sehingga pekerja khawatir bahwa dana JHT tidak dapat diambil kembali. Linda Darnel juga menekankan bahwa UU SJSN tidak memasukan pembahasan kondisi tertentu yang diartikan pengambilan manfaat JHT kepesertaan 5 tahun 1 bulan karena ingin menegaskan bahwa JHT merupakan jaminan yang diperuntukan ketika peserta memasuki usia pensiun. Hal ini menunjukan bahwa JHT diperuntukan bagi peserta yang memasuki usia pensiun atau mengalami resiko yang mengakibatkan hilangnya pendapatan.

Tuntutan Serikat Buruh ini kemudian direspon oleh Pemerintah dengan menerbitkan Peraturan Pemerintah Nomor 60 Tahun 2015 dan peraturan turunan di bawahnya yakni Permenaker Nomor 19 Tahun 2015. Kebijakan ini diambil pemerintah agar Serikat Pekerja berhenti melakukan demonstrasi yang tidak membuat gejolak yang berlebihan. Timboel Siregar selaku Koordinator BPJS Watch mejelaskan bahwa repson Pemerintah melebihi tuntutan pekerja sehingga pada akhirnya pekerja dapat mengambil kapanpun saat mereka terPHK dan mengundurkan diri. Timboel berpendapat bahwa kebijakan yang 
diambil pemerintah merupakan kebijakan populis dan akhirnya berdampak luas. Ini berdampak pada pengambilan dana JHT yang terus menerus sehingga pekerja ketika terkena PHK langsung mengambil manfat JHT berupa uang tunai ini. Ini tentunya berdampak pada sulitnya pelaksanaan pengembangan dana JHT dalam jangka waktu yang panjang sehingga pengembalian hasil pengembangan dana JHT kepada peserta tidak dapat optimal. Ahmad Ansyori sebagai Anggota DJSN dari unsur ahli menambahkan bahwa saat ini BPJS ketenagakerjaan belum memiliki target untuk pengembangan dana JHT sehingga masih terpaku dengan persentase yang dianggap aman karena masih berada di atas bunga deposito. Pada kenyataannya, BPJS ketenagakerjaan harus berinovasi untuk memberikan pengembangan dana yang baik sehingga prinsip SJSN yang ke 9 yakni memberikan sebesar-besarnya manfaat bagi peserta dapat tercapai. Adanya disharmoni regulasi dari Permenaker terhadap Peraturan Pemerintah Nomor 46 Tahun 2015 dan Undang-Undang SJSN ini menjadi fenomena yang lahir dari sebuahimplementasi kebijakan yang melibatkan berbagai aktor dan pelaksana

Pembahasan mengenai pergeseran filosofi manfaat JHT yang menyebabkan pergeseran filosofi JHT itu sendiri pada dasarkan tidak terlepas dari jaminan sosial bagi pekerja yang ingin diberikan oleh Pemerintah. Keputusan yang diperoleh pemerintah tidak terlepas untuk menjamin kelangsungan hidup pekerja disaat pekerja mengalami kehilangan pendapatan namun saja pengambilan keputusan tersebut dianggap kurang tepat bagi DJSN dan BPJS Watch sehingga perlu adanya telaah kembali. Implementasi Peraturan Pemerintah Nomor 46/2015 dianggap paling tepat untuk saat ini tanpa adanya PP Nomor 60 Tahun2015 dan Permenaker 2015. Implementasi kebijakan manfaat dari JHT tentunya melibatkan banyak aktor, strategi, tekanan, dan karakter dari pengambil keputusan.

2. Faktor-Faktor yang mempengaruhi Implementasi kebijakan manfaat JHT

Grindle menyatakan bahwa implementasi kebijakan merupakan proses politik dan administrasi pemerintahan. Implementasi kebijakan dapat dimulai saat sasaran telah ditetapkan, program kegiatan telah tersusun dengan baik, pendanaan telah dialokasikan untuk mencapai tujuan. Implementasi kebijakan manfaat
JHt dapat mencapai tujuannya bila tindakan yang dilakukan benar dalam implementasi kebijakan terssebut. Menurut Grindle Keberhasilan suatu implementasi kebijakan publik, ditentukan oleh tingkat implementability kebijakan itu sendiri yang terdiri atas Content of Policy dan Context of Policy. Isi kebijakan (Content of policy) ini antara lain meliputi:

a. Content of Policy (Isi Kebijakan)

- Kepentingan-kepentingan yang mempengaruhi

Dalam implementasi kebijakan manfaat JHT terdapat kepentingan-kepentingan yang mempengaruhi yakni kepentingan pekerja, kepentingan pemberi kerja dan kepentingan pemerintah. Pekerja menginginkan adanya jaminan ketika mereka memasuki masa pensiun untuk mempersiapkan masa tuanya. Pemberi kerja membagi beban dari iuran kepada pekerja untuk menyetorkan tabungan wajib pekerja. Iuran Program JHT menurut UU SJSN dan peraturan pelaksana dibawahnya sebesar $5,7 \%$ dari gaji/upah yang didaftarkan untuk pekerja sektor formal dan informal disesuaikan dengan gaji/upah yang didaftarkan dan jenis pekerjaannya. Pada pekerja sektor formal, pemberi kerja menanggung $3,7 \%$ dan pekerja sebesar 2\%. Pemerintah berkepentingan untuk memastikan pekerja Indonesia memiliki jaminan ketika mereka memasuki usia tua atau mencapai pensiun.

- $\quad$ Tipe manfaat

Berdasarkan UU SJSN yang diturunkan melalui PP Nomor 46 Tahun 2015 manfaat JHT adalah berupa uang tunai yang diberikan kepada peserta ketika peserta memasuki usia pensiun, cacat tetap dan meninggal dunia. Ahmad Ansyori menegaskan bahwa setiap manusia termasuk pekerja tentunya akan mengalami masa tua sehingga dirasa perlu untuk memberikan jaminan kepada peserta ketika mereka memasui usia pensiun. Dana tersebut dapat digunakan untuk menyelesaikan hal-hal yang belum terselesaikan saat bekerja atau pun menjadi modal awal bagi pekerja memasuki dunia yang baru.

- Derajat Perubahan yang ingin dicapai JHT telah ada sejak tahun 1992 melalui Undang-Undang Jamsostek namun di era 
SJSN yang ditandai dengan terbitnya Undang-Undang SJSN tahun 2004 maka kondisi tertentu yang ada dalam UndangUndang Jamsostek dan diartikan pengambilan dana JHT dengan kepesertaan 5 tahun ditiadakan. Perubahan ini dilakukan untuk meningkatakan kesadaran peserta akan pentingnya memiliki tabungan wajib yang dapat digunakan pada masa tua mereka sehingga persiapan memasuki dunia pensiun bisa lebih matang dan aman dengan kepesertaan wajib. Hal ini ditanggapi dengan adanya peningkatan kepesertaan jaminan sosial ketenagakerjaan termasuk program JHT, seperti tabel di bawah ini :

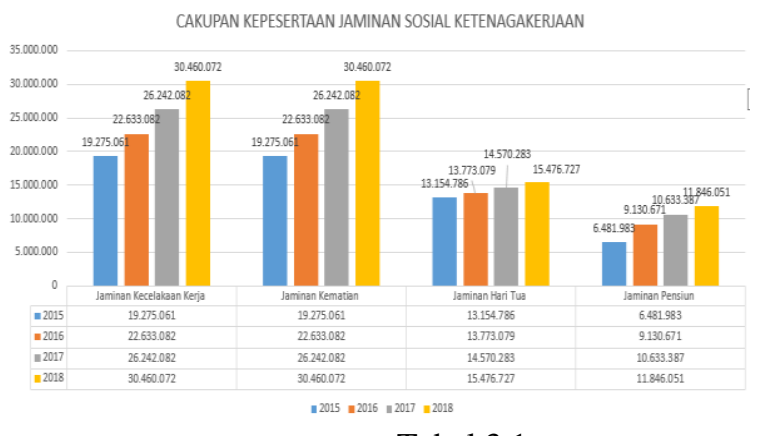

Tabel 3.1.

Cakupan Kepesertaan BPJS

Ketenagakerjaan Per tanggal 31

Desember 2017

Sumber : Data Olahan dari Laporan

BPJS Ketenagakaerjaan 2018

Kepesertaan program JHT meningkat dari tahun ke tahun. Sejak terbitnya UndangUndang Nomor 40 Tahun 2004 tentang Sistem Jaminan Sosial Nasional (Undang-Undang SJSN) maka kepesertaan pada jaminan hari tua dilakukan secara bertahap dan pada tahun 2029 ditargetkan akan mencapaiuniversal coverage di Indonesia. Pada tahun 2014 peserta program JHT berjumlah 12.724.248 jiwa kemudian meningkat pada tahun 2015 menjadi 13.154.786 jiwa. Pada tahun 2016 kepesertaan program JHT mencapai 13.773.079 dan selanjutnya di tahun 2017 mencapai 14.570.283. Peningkatan kepesertaan program JHT ini juga mencakup pada pekerja sektor formal dan informal (BPJS, 2017). Berdasarkan data tersebut maka tenaga kerja yang memiliki manfaat program JHT baru mencapai $11,4 \%$. Walaupun terjadi peningkatan kepesertaan namun tetap menunjukan masih rendahnya kesadaran baik dari pemberi kerja maupun pekerja untuk memikirkan masa depan atau masa ketika pekerja memasuki usia pensiun (BPJS, 2018).

Letak Pengambilan Keputusan

Kebijakan manfaat JHT ditetapkan dalam UU SJSN sehingga pengambilan keputusannya dilakukan oleh DPR kemudian peraturan pelaksananya ialah PP 46/2015 dengan inisiator Kemenaker dan perubahannya yakni PP 60/2015 serta Peraturan Menteri Ketenagakerjaan sehingga letak pengambilan keputusan dalam implementasi kebijakan manfaat JHT ada pada Presiden dan Kementerian Ketenagakerjaan RI.

Pelaksana Program

Pelaksana program JHT yakniBPJS Ketenagakerjaan. Pelaksana ini memiliki pengaruh terhadap implementasi kebijakan manfaat JHT. BPJS Ketenagakerjaan sebagai penyelenggara harus dapat berinovasi untuk menarik minat sekaligus menambah kesadaran pekerja dan pemberi kerja untuk mendaftarkan diri dalam program jaminan sosial ketenagakerjaan, salah satunya JHT. BPJS Ketenagakerjaan memiliki peran penting dalam perwujudan prinsip ke 9 dari SJSN yakni Pengelolaan Dana Jaminan Sosial Nasional dipergunakan seluruhnya untuk pengembangan program dan untuk sebesarbesarnya kepentingan peserta. Ahmad Ansyori sebagai Anggota DJSN menyampaikan bahwa peraturan saat ini hanya mengakomodir bahwa dana pengembangan JHT harus di atas Bungan deposito, sebaiknya BPJS Ketenagakerjaan memiliki target dari pengembangan dana program JHT dengan angka pasti misalnya $5 \%$ dari bunga desposito atau lebih sehingga BPJS ketenagakerjaan mampu menciptakan kondisi yang optimal bagi pengembangan hasil tabungan wajib peserta. Hal ini dilakukan dengan mengedepankan prinsip kehati-hatian.Dana pengembangan ini menjadi penting karen jumlah aset JHT merupkan jumlah aset terbesar. Data aset JHT dapat dilihat di bawah ini: 
Tabel 3.2

Pencapaian Asset Jaminan Sosial

Ketenagakerjaan per 31

Desember 2017

\begin{tabular}{|l|r|r|r|}
$\begin{array}{l}\text { ASET } \\
\text { PROGRAM }\end{array}$ & \multicolumn{1}{|c|}{$\mathbf{2 0 1 5}$} & \multicolumn{1}{c|}{$\mathbf{2 0 1 6}$} & \multicolumn{1}{c|}{$\mathbf{2 0 1 7}$} \\
\hline Jaminan & 14.148 .686$. & 18.973 .789$. & 24.120 .807$. \\
\hline Kecelakaan & 133.765 & 484.903 & 511.671 \\
Kerja & & & \\
\hline Jaminan & 4.638 .021$. & 6.362 .652$. & 8.346 .200$. \\
Kematian & 851.442 & 956.249 & 788.737 \\
\hline Jaminan & 181.948 .210$. & 217.708 .044$. & 254.208 .066$. \\
Hari Tua & 097.861 & 409.357 & 437.198 \\
\hline Jaminan & 2.668 .396$. & 12.195 .006$. & 25.667 .069$. \\
Pensiun & 481.480 & 215.997 & 388.586 \\
\hline
\end{tabular}

Sumber : Data Olahan Peneliti berdasarkan Laporan Keuangan BPJS Ketenagakerjaan, 2017

Berdasarkan data di atas maka dapat dilihat aset terbesar terdapat pada program Jaminan Hari Tua (JHT), ini menekankan bahwa pengelolaan aset yangbaik dapat bermanfaat pada pengembalian yang optimal bagi peserta.

Pelaksana lain dari program adalah pekerja dan pemberi kerja. Pekerja sebagai peserta yang menerima manfaat memiliki peran penting dalam implementasi kebijakan manfaat JHT. Peserta membayar iuran JHT berdasarkan upah yang diterima. Dalam halini upah yang menjadi acuan dasar iuran ialah gaji dan tunjangan tetap sesuai yang telah ditetapkan dalam PP 46 tahun 2015 tentang Penyelenggaraan Jaminan Hari Tua. Pemberi kerja memberikan dukungan sebagai pelaksana dengan membayarkan sebagian iuran sebesar $3,7 \%$ dari upah pekerja.

- Sumber-sumber daya

Implementasi kebijakan manfaat JHT tidak ada berhasil tanpa adanya sumber-sumber daya yang digunakan dengan baik. Sumber daya yang ada ialah kecukupan pendanaan, pemahaman, pegawai yang berkinerja baik, sistem IT yang memadai, regulasi yang baik, dan sebagainya.

b. Context of Policy (Lingkungan Kebijakan)

- Kekuasaan, kepentingan-kepentingan, dan strategi dari aktor yang terlibat (Power, Interest, and Strategy of-Actor Involved)
Implementasi kebijakan manfaat JHT dipengaruhi oleh kekuasaan, kepentingan, strategi dari aktor yang terlibat. Hal ini ditandai adanya pergerakan serikat pekerja yang menuntut adanya perubahan masa kepesertaan dalam pengambilan manfaat JHT. Hasil wawancara dengan Bapak Andi Awaluddin selaku Kepala Sub Direktorat kepesertaan Jaminan Sosial, untuk mengakomodir tuntuan pekerja, berbagai kementerian, termasuk kemenaker dan Kemenkumham bersinergi untuk melakukan pembahasan sehingga dikeluarkanlah keputusan untuk merevisi PP 46 Tahun 2015. Keputusan tersebut dilakukan guna menjaga stabilitas sosial dan ekonomi. Pernyataan tersebut ditambahkan dalam implementasinya terdapat celah kepada pekerja yang mengundurkan diri dan menyebabkan usia produktif banyak yang menarik JHT.

- Karakteristik lembaga dan rezim yang berkuasa (Institution and Regime Characteristic)

Karakteristik rejim yang berkuasa menjadi sangat kuat untuk mempengaruhi implementasi kebijakan manfaat JHT di Indonesia. Tuntuan pekerja untuk mengembalikan pengambilan manfaat JHT seperti saat penyelenggaraan PT JAMSOSTEK yakni kepesertaan 5 tahun 1 bulan bahkan dapat diambil kapan pun diharapkan juga dapat mengakomodir adanya jaminan bagi mereka yang berhenti bekerja. Pemerintah melalui Peraturan Menteri Ketenagakerjaan Nomor 19 tahun 2015 membuat keputusan bahwa manfaat JHT dapat diambil kapanpun saat pekerja berhenti kerja yang didefinisikan menjadi ter-PHK dan mengundurkan diri. Strategi pemerintah nyatanya memberikan pengaruh yang sangat signifikan terhadap implementasi kebijakan manfaat JHT itu sendiri baik dari segi regulasi, maupun tata kelola bagi pengembangan dana JHT.

- Tingkat kepatuhan dan adanya respon dari pelaksana (Compliance and Responsiveness).

Berdasarkan Pasal 11 Undang-Undang Nomor 24 tahun 2011 tentang BPJS, wewenang BPJS salah satunya ialah melakukan pengawasan dan pemeriksaan 
atas kepatuhan Peserta dan Pemberi Kerja dalam memenuhi kewajibannya sesuai dengan ketentuan peraturan perundangundangan jaminan sosial nasional. Pemberi kerja masih banyak yang melakukan Perusahaan Daftar Sebagian (PDS) baik upah, program dan tenaga kerja. Sesuai dengan data pada table 3.1. kepesertaan JKK/JKM jauh lebih tinggi dibandingkan JHT. Ini memperlihatkan bahwa tidak semua perusahaan mendaftarkan seluruh program kepada pekerjanya. Saat ini BPJS Ketenagakerjaan melakukan tugas dan fungsinya sesuai dengan dan menyelenggarakan program JHT berdasarkan kebijakan manfaat JHT yakni Permenaker Nomor 19 tahun 2015. BPJS sebagai penyelenggara mematuhi target kinerja dan merespon antusias yang tinggi dalam klaim JHT. BPJS Ketenagakerjaan memfasilitasi peserta dengan memberikan sistem online untuk setiap klaim dan pemantauan saldo JHT. Kepatuhan dan adanya respon dari BPJS ketenagakerjaan memberikan ruang tetap berjalananya implemenatasi kebijakan manfaat JHT bagi peserta.

Grindle mengemukakan padangan implmentasi kebijakan melalui satu rantai komando sehingga pemikiran bahwa implementasi top-down sangat melekat dalam faktor yang menentukan implementasi kebijakan. Rippley dan Franklin mencoba menegaskan bahwa implementasi kebijakan tidak hanya dilihat sebagai sebuah komando tetapi lebih dari itu yakni perlu adanya perhatian untuk pandangan-pandangan individu dan organisasi. Teori yang dibahas oleh Rippley dan Franklin ini ialah Hybrid yang merupakan gabungan antara model top-down dan bottom-up dari implementasi kebijakan. Implementasi kebijakan JHT tidak dapat hanya melihat dari sisi pemerintah namun melihat cara pandang pekerja sebagai peserta. Pekerja menyadari adanya kebutuhan mencairkan dana JHT ketika ter PHK namun mereka mulai menyadari bahwa JHT yang ditempatkan menjadi Jaminan Hari Tertentu bukan merupakan kebijakan yang tepat untuk menempatkan JHT. Riplley dan Franklin melihat implementasi melalui pendekatan kepatuhan dan pendekatan faktual. Pendekatan kepatuhan melihat BPJS ketenagakerjaan harus mematuhi peraturan yang telah ditetapkan termasuk untuk mengumpulkan dana jaminan sosial sesuai dengan ketentuan yang berlaku. Hal ini menegaskan BPJS memiliki peran penting dalam keberhasilan implementasi manfaat JHT karena mampu mengantisipasi adanya Perusahaan Daftar Sebagiann (PDS) baik program, upah dan tenaga kerja. Untuk pendekatan faktual yakni secara sosiologis maka pekerja memiliki kekhawatiran bukan hanya kehilangan pendapatan di saat tua namun pada usia produktif. Hal ini mengakibatkan pekerja dianggap terpaksa mencairkan manfaat JHT ketika terPHK walaupun masih dalam usia produktif. Menurut Subiyanto, perwakilan dari serikat pekerjamenyampaikam bahwa jaminan sosial saat tidak bekerja atau unemployeement benefit harus ada untuk menopang pekerja yang mengalami PHK sehingga dapat membantu kehidupannya hingga dapat bekerja kembali. Ini sebaiknya tidak mengambil dari dana JHT sehingga dana JHT dapat tetap diterima oleh peserta ketika memasuki usia pensiun.

\section{PENUTUP}

\section{simpulan}

Implementasi kebijakan manfaat JHT di Indonesia telah berjalan dengan memperhatikan faktor sosial yang terjadi, yakni masih banyaknyastatus pekerja kontrak/outsourching sehingga PHK menjadi hal yang dapat menghilangkan pendapatan dan beresiko terhadap pekerja walaupun pada usia produktif. Hal ini menyebabkan Permenaker Nomor 19 Tahun 2015 bertentangan dengan UndangUndang SJSN yang memiliki pandangan bahwa JHT harus diperuntukanbagi keperluan hari tua sehingga peserta mampu menghadapi masa pensiun yang lebih sejahtera. Implementasi kebijakan manfaat JHT dipengaruhi oleh berbagai hal, baik dari isi kebijakan maupun lingkungan kebijakan. Isi kebijakan mencakup kepentingan, jenis manfaat, perubahan yang diinginkan, kedudukan pembuat kebijakan, pembuat kebijakan, pelaksana program, dan sumber daya. Selain itu, lingkungan kebijakan yang mendukung adanya pergeseran filosofi JHT membuat implementasi kebijakan JHT tidak hanya menjadi jaminan ketika tua namun dapat menjadi jaminan ketika kehilangan penghasilan dengan konsekuensi yang sangat 
besar yakni pesert tidak lagi memiliki dana di hari tuanya kelak. Kepatuhan dan faktual menjadi hal yang juga mempengaruhi implementasi kebijakan manfaat JHT namun sudah sebaiknya pemerintah memiliki jalan keluar yang lebih baik agar JHT tetap diperuntukan untuk pekerja yang memasuki usia pension. Hal lain yang harus dipertimbangkan ialah pemerintah mengakomodir kebutuhan pekerja saat terPHK dengan bentuk perlindungan sosial yang lain guna membantu peserta tersebut menghadapi masa sulit hingga dapat bekerja kembali.Keberhasilan Implementasi kebijakan manfaat JHT di Indonesia dalam mencapai tujuannya memerlukan adanya sinkrosisasi pada aspek filosofis, sosiologi dan yuridis dari kebijakan tersebut.

\section{Saran}

1. Pemerintah perlu mengembalikan JHT kepada filosofi yang awal sehingga Peraturan Pemerintah Nomor 60 Tahun 2015 perlu dicabut untuk mewujudkan sinkronisasi regulasi.

2. Pemerintah dapat mempertimbangkan adanya kebijakan untuk pekerja yang terPHK dan mengundurkan diri secara terpisah dari JHT sehingga adanya kebijakan unemployeement benefit untuk memberikan perlindungan saat pekerja kehilangan pendapatan dan pemberian pelatihan/softskill untuk kebutuhan SDM Indonesia dalam menghadapi uncertainty world.

3. BPJS Ketenagakerjaan perlu melakukan upaya yang inovatif dan kreatif untuk dapat mengembangkan Manfaat Layanan Tambahan (MLT) sehingga mampu menarik minat pekerja untuk menjadi peserta.

4. BPJS Ketenagakerjaan perlu lebih tegas dalam melaksanakan kewenangan yakni menagih pembayaran iuran dan melakukan pengawasan dan pemeriksaan atas kepatuhan Peserta dan Pemberi Kerja dalam memenuhi kewajibannya sehingga tidak terdapat piutang.

\section{DAFTAR PUSTAKA}

Anderson, James E. (1979). Public Policy Making. New York: Holt, Rinehartand Winston.

Creswell, John W. 2009. Research Design : Qualitative, Quantitative, and Mixed Methods Approaches. Newbury Park: Sage Publications.

Devereux, S. and Sabates-Wheeler, R. (2004) Transformative Social Protection, IDS Working Paper, 232, Brighton: Institute of Development Studies.

Dunn, William N. (2003). Analisis Kebijakan Publik. Yogyakarta: Gadjah Mada. University Press.Dye, Thomas R, 2005, Understanding Public Policy, Eleventh Edition, New. Jersey: Pearson. Prentice Hall.

Pressman, Jeffrey L. and Wildavsky, Aaron B.. (1973). Implementation: How Great Expectations in Washington Are Dashed in Oakland. Berkeley: University of California Press

Grindle, Merilee S. (1980). Politics dan Policy Implementationin The Third World. New Jersey: Princeton University Press

Lasswell, Harold D A . 1971. Preview of Policy Sciences, New York: American Elsevier Publishing Co., 1971 Bardach

Mazmanian, Daniel H dan Paul A. Sabatier. (1983). Impelemention and Public Policy, New York : HarperCollins.

Midgley, James. (1995). The Developmental Perspective in Social Welfare. Sage.

Neuman, W Laurence. (2007). Social Research Methods, Qualitative and Quantitative. Approaches.4th ed. USA : Allyn \& Bacon.

Ripley, Randall B. \& Franklin, Grace A.. (1986). Policy Implementation and Bureaucracy. The Dorsey Press. Chicago Illinois.

Suharto, Edi. (2007). Kebijakan Sosial Sebagai

Kebijakan Publik. Bandung: Alfabeta

Suyanto, Bagong. (2010). Metode Penelitian Sosial. Jakarta Prenada Media Group

Situmorang, Chazali H. (2016). DinamikaPenyelenggaraan Jaminan Sosial Di Era SJSN. Depok : Social Security Development Institut (SSDI).

https://www.unicef.org/socialpolicy/files/Transfor mative_Social_Protection.pdf

http://www.jamsosindonesia.com/cakrawala/perusa haan_daftar_sebagian_upah_karyawan_menjadi _korban

Undang-Undang Nomor 40 Tahun 2004 Tentang

Sistem Jaminan Sosial Nasional 
Undang-Undang Nomor 24 Tahun 2011 Tentang Badan Penyelenggara Jaminan Sosial

Peraturan Pemerintah Nomor 46 Tahun 2015 Tentang Penyelenggaraan Jaminan Hari Tua

Peraturan Pemerintah Nomor 60 Tahun 2015 Tentang Perubahan Peraturan Pemerintah Nomor 46 Tahun 2015 Tentang Penyelenggaraan Jaminan Hari Tua

Peraturan Menteri Ketenagakerjaan Nomor 19 Tahun 2015 Tentang Tata Cara dan Persyaratan Pembayaran Manfaat Program Jaminan Hari Tua 